Int. J. Electrochem. Sci., 15 (2020) 7935 - 7953

International Journal of

ELECTROCHEMICAL

SCIENCE

WWW.electrochemsci.org

\title{
A Novel Battery State of Charge Estimation Based on the Joint Unscented Kalman Filter and Support Vector Machine Algorithms
}

\author{
Fei Xie ${ }^{1}$, Shunli Wang ${ }^{1, *}$, Yanxin Xie ${ }^{1}$, Carlos Fernandezb ${ }^{2}$, Xiaoxia Li ${ }^{1}$, Chuanyun Zou ${ }^{1}$ \\ ${ }^{1}$ School of Information Engineering, Southwest University of Science and Technology, Mianyang \\ 621010, China; \\ ${ }^{2}$ School of Pharmacy and Life Sciences, Robert Gordon University, Aberdeen AB10-7GJ, UK. \\ *E-mail: wangshunli@,swust.edu.cn
}

doi: $10.20964 / 2020.08 .83$

Received: 5 January 2020 / Accepted: 12 February 2020 / Published: 10 July 2020

\begin{abstract}
With the development of new energy sources becoming the mainstream of energy development strategies, the role of electric vehicle-powered lithium-ion batteries in the field of automobile transportation is becoming more and more obvious. An efficient the Battery Management System is necessary for the real-time usage monitor of each battery cell, which analyzes the battery status to ensure its safe operation. A complex equivalent circuit model is proposed and established. the Improved Equivalent Circuit Model is used to realize the precise mathematical expression of the power lithiumion battery packs under special conditions. The State of Charge estimation method which is based on Unscented Kalman Filter has a good filtering effect on the nonlinear systems. Based on the State of Charge estimation of Support Vector Machine, the samples in the nonlinear space of lithium-ion battery are mapped to the linear space. It can be seen from the experimental analysis that a joint Unscented Kalman Filter and Support Vector Machine algorithms for State of Charge estimation has higher accuracy. The experimental results show that the tracking error is less than $1.00 \%$.
\end{abstract}

Keywords: Battery Management System; State of Charge; Improved Equivalent Circuit Model; Unscented Kalman Filter; Support Vector Machine

\section{FULL TEXT}

(C) 2020 The Authors. Published by ESG (www.electrochemsci.org). This article is an open access article distributed under the terms and conditions of the Creative Commons Attribution license (http://creativecommons.org/licenses/by/4.0/). 